\title{
Rancang Bangun Sistem Monitoring Denyut Jantung SpO2 dan Suhu Tubuh Penderita COVID-19 Berbasis IoT
}

\author{
${ }^{1}$ Arsa Rizky Imanda, ${ }^{2}$ Sayyidati Zuhroh*, ${ }^{3}$ Mukhamad Azis Tholib \\ Prodi S1 Fisika, Universitas Negeri Malang, Indonesia \\ e-mail: arsarizkyimanda@gmail.com; sayyidatiz5@gmali.com; mukhammadazistholib278@gmal.com
}

\begin{abstract}
Abstrak
Telah berhasil diciptakan alat monitoring denyut jantung, saturasi oksigen $\left(\mathrm{SpO}_{2}\right)$ dalam darah, dan suhu tubuh penderita COVID-19 berbasis loT. Alat ini berupa gelang yang mana terdiri dari beberapa alat penting, yaitu NodeMCU ESP8266, TCA9548A, Icd oled $128 \times 64$ pixel, sensor AD8232, sensor MAX30100, dan sensorMPU6050. Alat ini ditujukan untuk penanganan penderita COVID-19 di Indonesia khususnya pasien rawat inap yang berada di rumah sakit darurat ataupun rumah sakit rujukan COVID-19. Metode analisis yang digunakan dalam penelitian ini adalah metode perbandingan, yaitu dengan membandingkan hasil ukur alat yang dibuat dengan alat ukur yang telah ada, seperti oximeter dan thermometer klinis. Hasil ukur denyut jantung menunjukan error yang besar, yaitu sebesar $4,12 \%$, sedangkan hasil ukur saturasi oksigen dan suhu tubuh memiliki error relatif kecil, yaitu sebesar 1,27\% dan $0,35 \%$. Hasil pengukuran dapat dilihat pada website Thingspeak.com dalam bentuk grafik. Pengiriman data dengan kecepatan internet 1,27 Mbps alat berhasil mengirimkan 16 dari 220 data dengan jeda 16-60 detik. Peletakan sensor denyut jantung yang tidak tepat memberikan error yang cukup besar.
\end{abstract}

Kata Kunci: denyut jantung, $\mathrm{SpO}_{2}$, suhu tubuh, penderita COVID-19

\section{Use of Perturbation Theory to Determine Particle Energy Levels on a Three-Dimensional Potential Box}

\begin{abstract}
The monitoring tool for heart rate, oxygen saturation $\left(\mathrm{SpO}_{2}\right)$ in blood, and body temperature for people with COVID-19 based on loT has been successfully created. This tool is in the form of a bracelet which consists of several important tools, namely NodeMCU ESP8266, TCA9548A, $128 \times 64$ pixel LCD oled, AD8232 sensor, MAX30100 sensor, and MPU6050 sensor. This tool is intended for handling COVID-19 sufferers in Indonesia, especially inpatients who are in emergency hospitals or COVID-19 referral hospitals. The analytical method used in this study is the comparison method, namely by comparing the results of measuring instruments made with existing measuring instruments, such as clinical oximeters and thermometers. The results of measuring heart rate showed a large error, which was $4.12 \%$, while the measurement results of oxygen saturation and body temperature had relatively small errors, namely $1.27 \%$ and $0.35 \%$. The measurement results can be seen on the Thingspeak.com website in graphical form. Sending data with an internet speed of $1.27 \mathrm{Mbps}$, the device successfully sends 16 out of 220 data with a delay of 16-60 seconds. Incorrect placement of the heart rate sensor gives a sizable error.
\end{abstract}

Keywords: heart rate, $\mathrm{SpO}_{2}$, body temperature, people with COVID-19

How to Cite: Rizky Imanda, A., Zuhroh, S., Azis Tholib, M. (2020). Rancang Bangun Sistem Monitoring Denyut Jantung SpO2 dan Suhu Tubuh Penderita COVID-19 Berbasis IoT. Jurnal

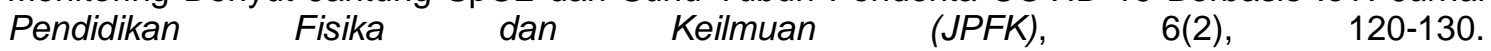
doi:http://doi.org/10.25273/jpfk.v6i2.7952 


\section{PENDAHULUAN}

Wabah virus corona telah menjadi ancaman klinis bagi masyarakat seluruh dunia (Lai et al., 2020). Virus ini dapat menyebabkan infeksi pada pernafasan manusia termasuk radang paru-paru, sementara pada hewan virus ini menyebabkan diare dan penyakit pernapasan bagian atas (Kasdan et al., 2020). Sejak 11 Maret 2020 lalu, WHO telah menetapkan virus corona sebagai pandemic global. Hingga saat ini dokter sekaligus Epidemiolog Dicky Budiman mengatakan bahwa virus corona memiliki potensi untuk menjadi penyakit endemic. Bagaimana tidak, penyebaran virus corona dinilai sangat signifikan dan sangat mudah dari manusia ke manusia lain. Terhitung hingga 30 November 2020 kasus positif COVID-19 global telah tercatat sebanyak 62.677 .879 jiwa dan kasus positif Indonesia sebanyak 534.266 jiwa (KPCPEN, 2020). Para dokter dan tenaga medis di seluruh dunia pun kewalahan dalam menangani pasien COVID-19 ini karena begitu banyaknya peningkatan setiap harinya. Langkah-langkah pencegahan terus dilakukan, seperti tindakan social distancing dan physical distancing yang bertujuan untuk memperlambat penyebaran penyakit dengan menghentikan rantai penularan COVID-19. WHO dan ECDC menyarankan untuk menghindari tempat-tempat umum dan menutup kontak dengan orang-orang yang terinfeksi dan hewan-hewan peliharaan (Gao et al., 2020).

Kasus COVID-19 dapat dibagi menjadi empat status, yaitu status orang dalam pengawasan (ODP), pasien dalam pengawasan (PDP), dan orang tanpa gejala (OTG), dan terkonfirmasi positif (KPCPEN, 2020). Sedangkan dalam penelitian ini dikhususkan untuk pasien COVID-19 rawat inap yang berada di rumah sakit darurat atau di rumah sakit rujukan. Salah satu gejala dari COVID-19 adalah sesak napas. Biasanya juga disertai dengan batuk, sakit tenggorokan, dan atau demam (suhu tubuh $\geq 38^{\circ} \mathrm{C}$ ) (Yurianto \& Bambang Wibowo, 2020). Beberapa pasien COVID-19 juga memiliki saturasi oksigen yang rendah (SpO2 < 90\% pada udara kamar) atau yang biasa disebut silent hipoxia. Yaitu suatu kondsi di mana tubuh pasien kekurangan oksigen secara mendadak namun tetap merasa nyaman dan tidak ada gejala apapun. Untuk itu, sangat penting untuk mengetahui suhu tubuh dan saturasi oksigen (SpO2) pasien COVID-19 tersebut.

Dalam penanganan pasien COVID-19, sangat diperlukan kehati-hatian. Sudah tidak sedikit dokter dan tenaga medis lain yang terinfeksi virus corona dalam mengangani pasien. Dimungkinkan mereka tertular karena kontak langsung dengan para pasien, atau karena kontak dengan alat-alat medis yang telah digunakan untuk menangani pasien, seperti stetoskop, oximeter, thermometer, dan sebagainya. Untuk mengatasi hal tersebut peneliti akan menciptakan suatu alat yang dapat membantu para dokter dan tenaga medis agar dapat mengurangi kontak langsung dengan pasien beberapa kali dalam penanganan pasien. Alat tersebut berupa gelang yang nantinya dipakaikan di tangan pasien. Gelang ini dilengkapi dengan mikroprosesor ESP8266 dan sensor Max30100 \& MPU6050 yang dihubungkan dengan software thinkspeak sehingga tenaga medis tidak perlu kontak dengan pasien beberapa kali untuk mengecek suhu, denyut jantung, dan saturasi oksigen pasien. Karena dengan gelang ini, suhu tubuh, denyut jantung, dan saturasi oksigen pasien dapat dilihat secara otomatis melalui website. Sehingga untuk mengetahui kapan si pasien memerlukan oksigen atau penanganan yang lain, dokter dapat hanya melihat melalui web tersebut.

Penelitian tentang monitoring denyut jantung dan saturasi oksigen dengan menggunakan sensor Max30100 telah dilakukan oleh Budi, dkk 2019 dalam 
penelitiannya yang berjudul "Sistem Deteksi Gejala Hipoksia Berdasarkan Saturasi Oksigen dan Denyut Jantung Menggunakan Metode Fuzzy Berbasis Arduino". Peneltian ini mendapat hasil pengujian dengan error alat yaitu 2,96\% untuk saturasi oksigen dan 2,86\% untuk denyut jantung (Budi et al.). Penelitian yang serupa juga dilakukan oleh Srushti Chavan yang berjudul "Solar Powered NonInvasive Pulse Oximeter and Heart Rate Meter" di mana menghasilkan ukuran denyut jantung dan $\mathrm{SpO} 2$ lima partisipan yang rata-rata 80 denyut per menit dan $98,23 \%$ masing-masing, alat ini mampu bertahan hingga lebih dari 40 jam (Chavan et al.). Selain itu penelitian Veriko Yonanto dkk. dengan judul "Pemantauan SpO2 Melalui Aplikasi Android di Mobile Phone". Hasil dari penelitian tersebut adalah alat mampu mengukur dengan rata-rata error 0,27\% (Lai et al., 2020).

Urgensi dalam penelitian ini adalah minimnya penelitian tentang penanganan COVID-19 di Indonesia. Selain itu, alat yang akan diciptakan ini merupakan alat yang berbasis loT sehingga mudah dan efisien untuk digunakan. Penelitian ini akan memberikan banyak manfaat karena dapat mengatasi permasalahan masyarakat Indonesia bahkan global dalam penanganan COVID-19.

\section{METODE PENELITIAN}

Penelitian ini merupakan penelitian berbasis data atau dapat disebut sebagai penelitian kuantitatif. Dalam penelitian ini dirancang sebuah alat untuk monitoring denyut jantung, $\mathrm{SpO}_{2}$, dan suhu tubuh pasien Penderita COVID-19. Penelitian ini dilakukan di Laboratorium Elektronika dan Instrumentasi Jurusan Fisika Universitas Negeri Malang. Beberapa metode yang dilakukan, yaitu tahap persiapan, tahap pelaksanaan, dan tahap analisis data. Secara lengkap metode penelitian akan dijelaskan oleh diagram alir berikut.

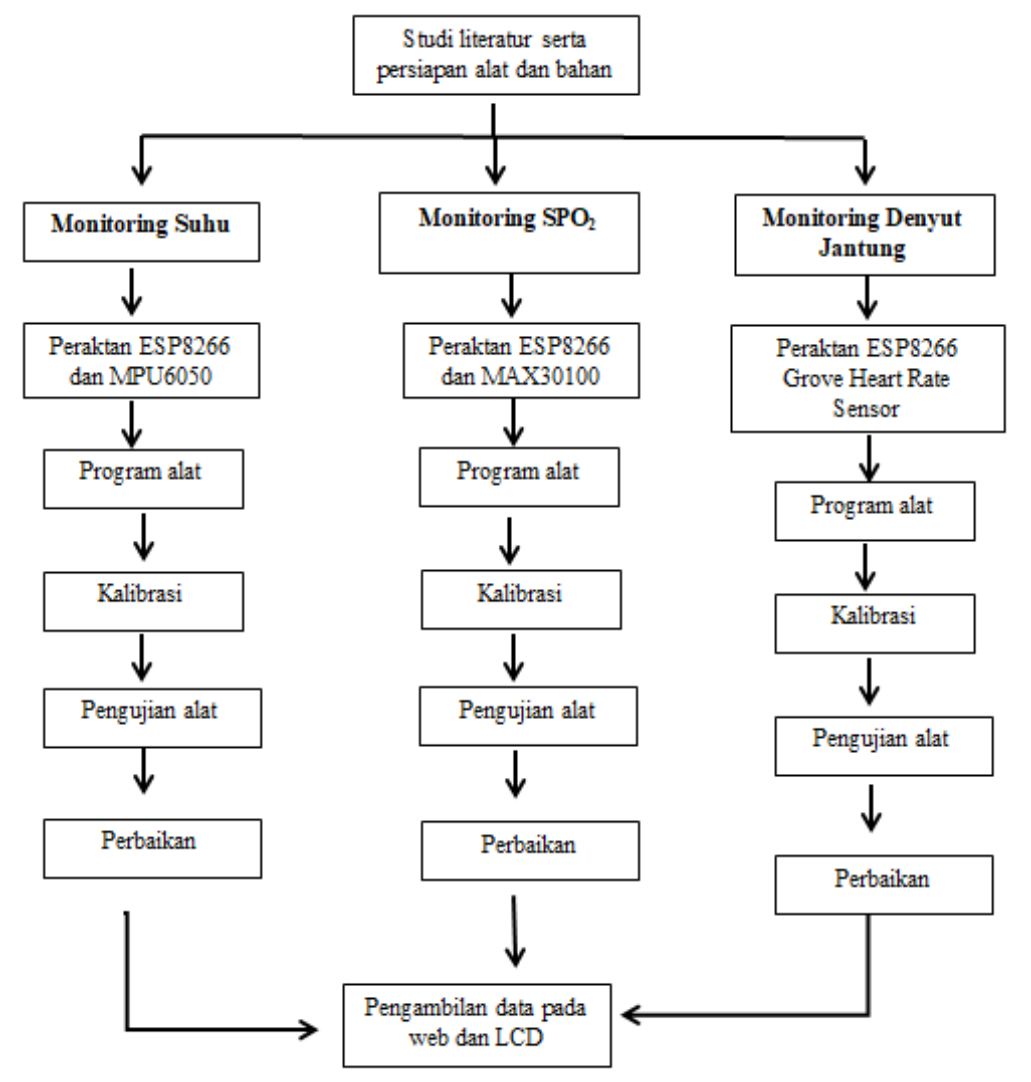

Jurnal Pendidikan Fisika dan Keilmuan (JPFK), Vol. 6, No. 2, September 2020, 120-130. 
Gambar 1. Diagram alir metode penelitian

\section{PERSIAPAN ALAT}

Dalam tahap ini disiapkan alat dan bahan yang digunakan dalam penelitian ini seperti berikut ini.

Alat : Avometer, Solder Sunshine SL-908 220V

Bahan : ESP 8266, MAX30100, MPU-6050, Kabel, Timah Solder, Power Bank XiaoMi Slim Pro 10000mAh, Baterai lithium polimer 600 mAh 603040$40 \times 30 \mathrm{~mm}$

\section{TAHAP PELAKSANAAN \\ Monitoring Suhu Tubuh}

Dalam tahap ini dilakukan beberapa langkah seperti a) merakit sensor suhu MPU 6050 dengan microprosesor ESP 8266, b) memprogram alat yang telah terakit, c) mengkalibrasi alat dengan termometer digital, d) melakukan pengukuran suhu tubuh pada lima pasien yang memiliki suhu tubuh tidak normal, e) melakukan pengujian alat, f) melakukan perbaikan apabila hasil pengukuran belum sesuai, $g$ ) melakukan pengukuran suhu tubuh pada sembilan reponden, dan $h$ ) menganalisis akurasi hasil pengukuran dan pengiriman data pada LCD dan web Thingspeak.

\section{Monitoring Denyut Jantung \& Saturasi Oksigen $\left(\mathrm{SpO}_{2}\right)$}

Dalam tahap ini dilakukan beberapa langkah seperti a) merakit sensor suhu MAX 30100 dengan microprosesor ESP 8266, b) memprogram alat yang telah terakit, c) mengkalibrasi alat dengan Fingertip Pulse Oximeter. Melakukan pengukuran pada lima pasien yang memiliki denyut jantung dan saturasi oksigen $\left(\mathrm{SpO}_{2}\right)$ di bawah normal, d) melakukan pengujian alat, e) melakukan perbaikan apabila hasil pengukuran belum sesuai, f) melakukan pengukuran denyut jantung dan saturasi oksigen $\left(\mathrm{SpO}_{2}\right)$ pada sembilan reponden, dan g) menganalisis akurasi hasil pengukuran dan pengiriman data pada LCD dan web Thingspeak.

\section{Metode Analisis}

Metode analisis dalam penelitian ini dilakukan dengan melihat apakah alat dapat berfungsi dengan baik dimana alat memberikan hasil pengukuran denyut jantung satuasi $\mathrm{O}_{2}$ dan suhu tubuh pasien dengan presisi dan akurat, serta alat dapat mengirimkan hasil pengukurannya tersebut melalui jaringan internet untuk memantau kesehataan pasien melalui web Thingspeak sebagai user interface. Di mana hasil pengukurannya dibandingkan dengan alat yang sudah ada, seperti oximeter dan thermometer klinis.

\section{HASIL DAN PEMBAHASAN}

Alat monitoring denyut jantung, saturasi oksigen $\left(\mathrm{SpO}_{2}\right)$, dan suhu tubuh penderita COVID-19 berbasis loT memiliki tiga sensor, yaitu sensor denyut jantung, sensor saturasi osigen dalam darah, dan sensor suhu. Skema elektrik alat tersebut dapat ditunjukkan pada Gambar 1. 


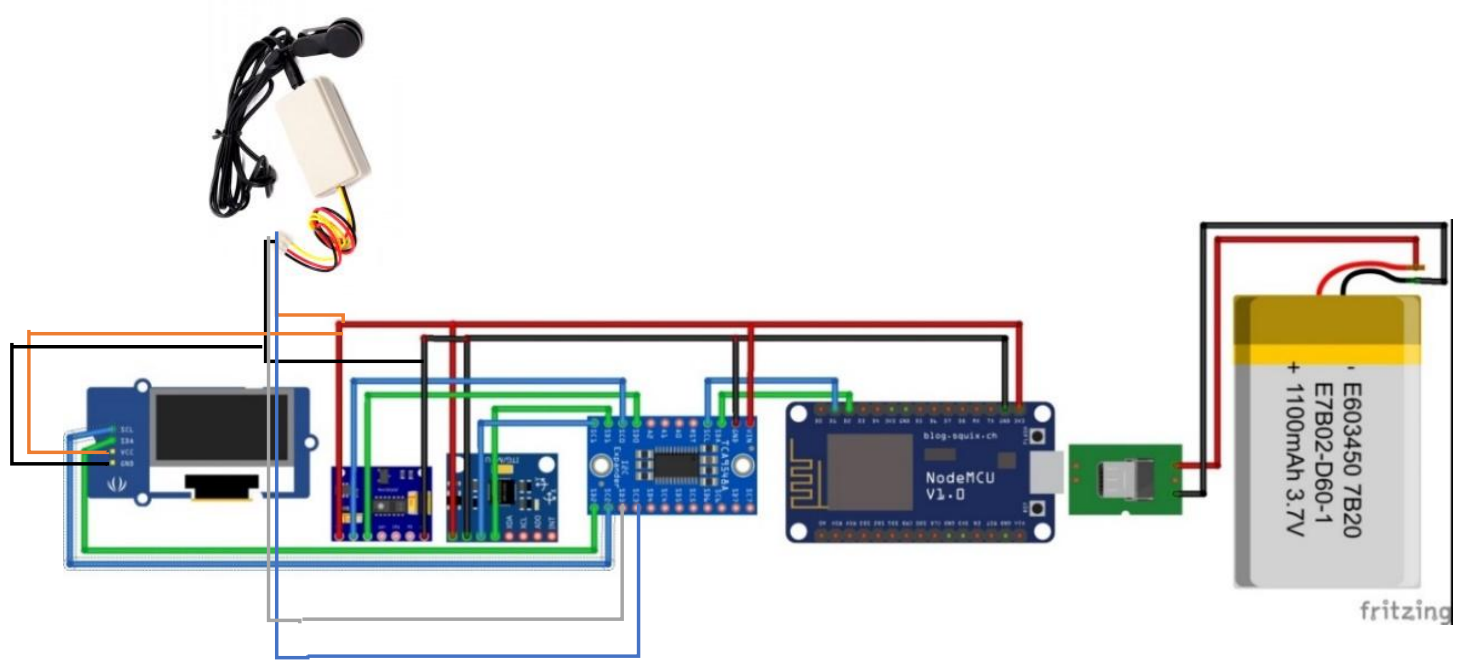

Gambar 1. Skema elektrik alat monitoring denyut jantung, saturasi oksigen $\left(\mathrm{SpO}_{2}\right)$, dan suhu tubuh penderita COVID-19

Sensor denyut jantung yang digunakan adalah AD8232 keluaran Grove. Dalam Sensor ini terdapat led hijau dan photodiode, cahaya yang keluar dari led akan diserap sebagian oleh pembuluh darah dan sebagian lagi akan dipantulkan, intensitas pantulan cahaya ini yang nantinya akan di terima oleh photodiode dan diterjemahkan menjadi laju denyut jantung permenit. Hasil pengukuran dari sensor ini dipengaruhi oleh tebalnya kulit dan banyaknya pembuluh da rah dibawah kulit. Idealnya sensor ini diletakkan di jari namun pada penelitian kali ini peneliti mencoba meletakkannya di pergelangan tangan. Hasilnya sensor bekerja kurang maksimal, terkadang hasil pembacaan melebihi $150 \mathrm{bpm}$ padahal hasil ukur menggunakan oximetry hanya mencapai $90 \mathrm{bpm}$.

Sensor saturasi oksigen yang digunakan dalam penelitian ini adalah MAX 30100. Idealnya sensor diletakkan di jari namun bisa juga dibagian tubuh lain yang memiliki pembuluh darah pada penelitian ini peneliti meletakkannya di pergelangan tangan. MAX 30100 menggunakan Led merah, infrared dan photodiode, keluaran infrared dan led merah akan dipantulkan oleh pembuluh darah kemudian ditangkap oleh photodiode, perbandingan intensitas cahaya led dan inframerah inilah yang kemudian diterjemahkan menjadi banyaknya oksigen dalam darah dimana perbandingan intensitas infrared dan cahaya led bergantung pada saturasi oksigen dalam pembuluh darah. Cahaya keluaran led merah terang dan redup secara periodik sehingga nilai saturasi oksigen hasil pembacaan membesar dan mengecil secara periodik, nilai yang mendekati hasil ukur oximetry adalah nilai ketika led merah menyala paling terang.

Sensor suhu yang digunakan dalam penelitian ini adalah MPU6050, sensor ini biasanya digunakan untuk mengukur suhu ruangan namun dalam penelitian ini peneliti menggunakannya untuk mengukur suhu tubuh. Sensor ditempelkan pada kulit tubuh sehingga sensor akan membaca suhu tubuh. Hasil pembacaan sensor ini memang cukup lama yakni 1 menit untuk kenaikan suhu $1^{\circ} \mathrm{C}$ namun memiliki hasil ukur yang akurat.

Di antara komunikasi sensor dan mikrokontroler terdapat multiplexer I2C yakni TCA9548A. Multiplexer digunakan karena pada nodeMCU hanya ada sepasang pin i2c sedangkan ketiga sensor dan oled masing-masing memerlukan sepasang pin i2c. Multiplexer berfungsi sebagai selector yang mengatur jalannya data, memilih slave yang dapat melakukan komunikasi serial dan slave mana yang 
harus menunggu. Jika tidak ada multiplixer maka alat akan error dan berhenti bekerja.

Mikrokontroler yang digunakan adalah NodeMCU ESP8266, NodeMCU ESP8266 dipilih sebagai mikrokontroler karena ukurannya yang kecil, bisa mengolah data juga terkoneksi internet. Mikrokontroler berfungsi untuk pengolah data hasil pembacaan sensor kemudian ditampilkan di lcd oled dan di kirimkan ke website thingspeak.com.

Perangkat yang digunakan utuk menampilkan data adalah Icd OLED dengan ukuran 128 x 64 pixel. Led-led dalam Icd ini akan menyala sesuai dengan program yang dimasukkan sehingga bisa membentuk gambar atau tulisan.

Platform loT yang digunakan untuk menampilkan data di website adalah thingspeak. Data yang ditampilkan di website thingspeak berupa grafik yakni grafik data pembacaan sensor terhadap waktu. Nilai dari grafik ini bisa disimpan atau didownload sehingga memudahkan untuk melakukan analisis. Thingspeak ini bisa di akses dimanapun dan kapanpun, bergantung pada koneksi internet pada saat itu.

Battrey yang digunakan adalah batrrey lithium polimer dengan kapasitas $1000 \mathrm{mAh}$ dan tegangan output 3,7 Volt. Dari hasil pengujian didapati dengan kapasitas 1000mAh alat mampu bertahan selama 6 jam. Tegangan input NodeMCU berkisar 3-5 Volt sehingga dengan tegangan batrrey 3,7 Volt NodeMCU dapat berfungsi dengan baik.

Berikut ini merupakan flowchart program dalam penelitian ini.

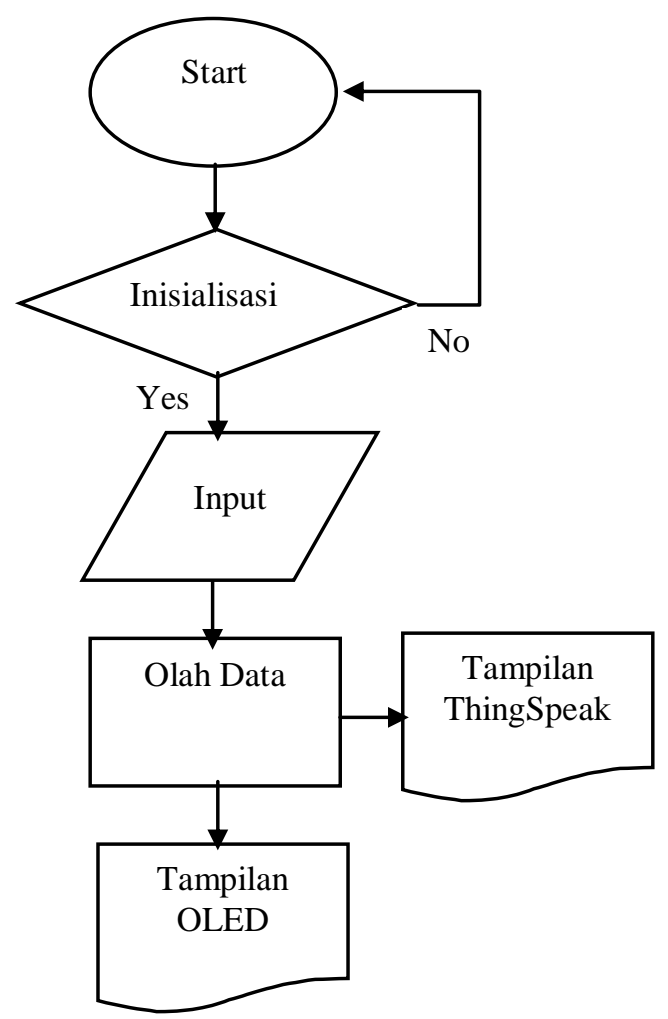

Gambar 2. Flowchart program 

Start : memulai menyalakan seluruh komponen
Inisialisasi : menginisialisasi sensor AD8232, sensor max 30100, sensor MPU6050 dan Icd oled. Jika semua berfungsi maka akan lanjut ke proses namun jika salah satu tidak berfungsi maka akan kembali ke start.
Input : sensor-sensor membaca detak jantung, kadar oksigen, dan suhu tubuh.
Proses $\quad$ : hasil pembacaan sensor di olah oleh mikrokontroler dan dikirim melalui jaringan internet
Oled : data yang telah diolah oleh mikrokontroler ditampilkan pada lcd oled Thingspeak : data yang dikirim oleh mikrokontroler ditampilkan dalam website thingspeak berupa grafik.

Pengujian alat dilakukan pada sembilan responden dengan cara menempelkan alat pada pergelangan tangan seperti pada Gambar 3. sebagai pembandingnya digunakan oximetry dan termometer badan.

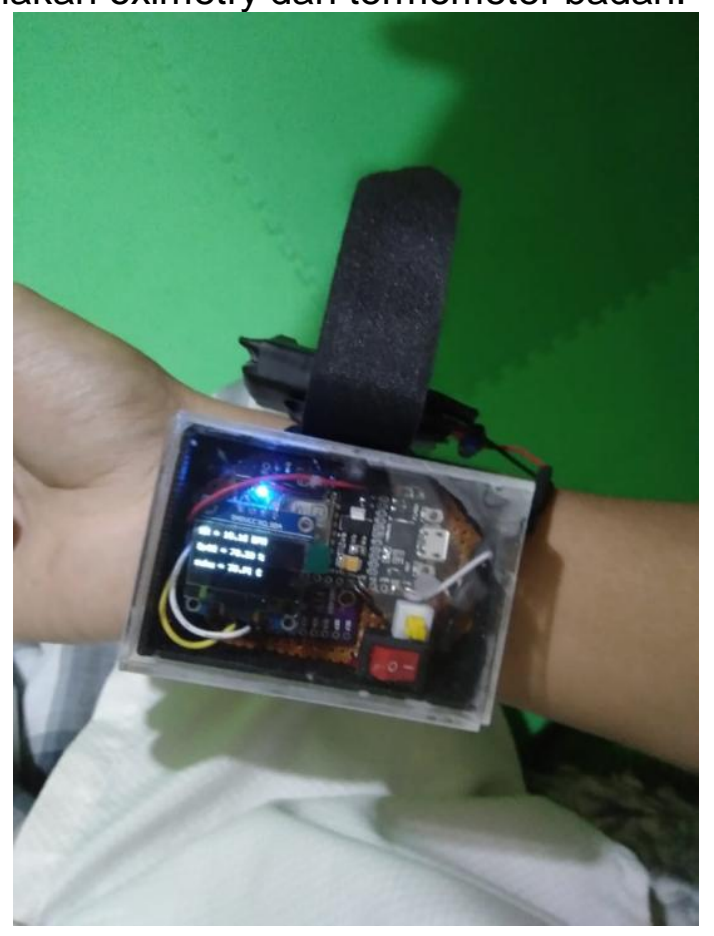

Gambar 3. Contoh pengambilan data

Hasil pembacaan laju denyut jantung mudah berubah sehingga menunggu setabil untuk melakukan pencatatan, sedangkan pengambilan data saturasi oksigen diambil ketika intensitas cahata led paling terang dan pengambilan data suhu tubuh menunggu hasil pembacaan MPU6050 tidak mengalami kenaikan lagi.

\begin{tabular}{|c|c|c|}
\hline $\begin{array}{c}\text { AD8232 } \\
\text { (BPM) }\end{array}$ & $\begin{array}{l}\text { Pulse Oximetry } \\
\text { (BPM) }\end{array}$ & Error (\%) \\
\hline 59,20 & 58 & 2,03 \\
\hline 69,05 & 67 & 2,97 \\
\hline 74,15 & 78 & 5,65 \\
\hline 78,90 & 74 & 6,21 \\
\hline
\end{tabular}




\begin{tabular}{ccc}
\hline $\begin{array}{c}\text { AD8232 } \\
\text { (BPM) }\end{array}$ & $\begin{array}{c}\text { Pulse Oximetry } \\
\text { (BPM) }\end{array}$ & Error (\%) \\
\hline 80,26 & 80 & 0,09 \\
81,96 & 91 & 11,43 \\
83,32 & 84 & 0,42 \\
86,04 & 83 & 3,92 \\
91,13 & 89 & 2,71 \\
\hline \multicolumn{3}{c}{} \\
\hline
\end{tabular}

Tabel 1 merupakan hasil pengukuran denyut jantung terhadap sembilan responden yang bergeda. Berdasarkan hasil pengukuran tersebut didapatkan selisih hasil ukur yang mengakibatkan error bekisar 0,42\% sampai $11,43 \%$ dengan rata-rata error sebesar 4,12\%. Selisih pengukuran terbesar mencapai 9,04 bpm. Sensor AD8232 idealnya digunakan pada jari namun pada penelitian ini mencoba mengenakannya pada pergelangan tangan hal ini berpengaruh pada intensitas cahaya yang masuk pada photodiode sehingga hasil ukur kurang maksimal.

\begin{tabular}{ccc}
\begin{tabular}{c} 
Tabel 2. Hasil Pembacaan Sensor Saturasi Oksigen \\
\hline $\begin{array}{c}\text { Max30100 } \\
(\%)\end{array}$
\end{tabular} & $\begin{array}{c}\text { Pulse Oximetry } \\
(\%)\end{array}$ & \begin{tabular}{c} 
Error $(\%)$ \\
\hline 95,98
\end{tabular} \\
96,12 & 97 & 1,06 \\
96,51 & 95 & 1,16 \\
96,51 & 97 & 1,22 \\
97,44 & 94 & 0,85 \\
97,70 & 98 & 3,19 \\
97,97 & 99 & 0,30 \\
97,97 & 98 & 0,71 \\
96,12 & 95 & 0,03 \\
\hline \multicolumn{3}{c}{ Rata-rata Error } \\
\hline
\end{tabular}

Tabel 2 merupakan hasil pengukuran saturasi oksigen dalam darah terhadap sembilan responden yang berbeda. Berdasarkan hasil pengukuran tersebut didapatkan selisih hasil ukur berkisar antara 0,23\% hingga 2,85\% dengan error bekirsar $0,03 \%$ sampai $3,19 \%$ dan rata-rata error sebesar $1,27 \%$.

\begin{tabular}{ccc}
\multicolumn{3}{c}{ Tabel 3. Hasil Pembacaan Sensor Suhu Tubuh } \\
\hline $\begin{array}{c}\text { MPU6050 } \\
\left({ }^{\circ} \mathbf{C}\right)\end{array}$ & $\begin{array}{c}\text { Termometer } \\
\left({ }^{\circ} \mathbf{C}\right)\end{array}$ & Error $(\%)$ \\
\hline 35,68 & 35,3 & 1,09 \\
35,82 & 36 & 0,51 \\
35,87 & 35,5 & 1,05 \\
35,87 & 36,5 & 1,72 \\
35,92 & 35,7 & 0,61 \\
35,96 & 36,2 & 0,66 \\
35,99 & 36 & 0,02 \\
35,99 & 36,3 & 0,85 \\
36,06 & 36,5 & 1,19 \\
\hline \multicolumn{3}{c}{ Rata-rata Error } \\
\hline
\end{tabular}

Tabel 3 menunjukan hasil pengukuran suhu tubuh terhadap sembilan responden yang berbeda. Menggunakan sensor MPU6050 yang bisa mengukur suhu sekitar dan termometer badan sebagai pembandingnya. Berdasarkan hasil pengukuran tersebut didapatkan beda hasil ukur berkisar antara 0,01 hingga 0,63 
derajat celcius dengan error berkisar antara 0,02 \% hingga 1,72 \% dan error ratarata 0,35 \%. Penggunaan sensor MPU 6050 umumnya digunakan untuk pengukuran suhu ruangan namun dengan didapatkannya error yang kecil penelitian ini mebuktikan MPU6050 juga cocok untuk pengukuran suhu tubuh. Pembacaan MPU6050 cukup lama yakni membutuhkan waktu kurang lebih 1 menit unuk mendeteksi kenaikan suhu sebesar $1^{\circ} \mathrm{C}$.

Pengiriman data melalui jaringan internet menggunakan ESP8266 yang dikoneksikan dengan wifi kemudian ditampilkan dalam website thingspeak.com.
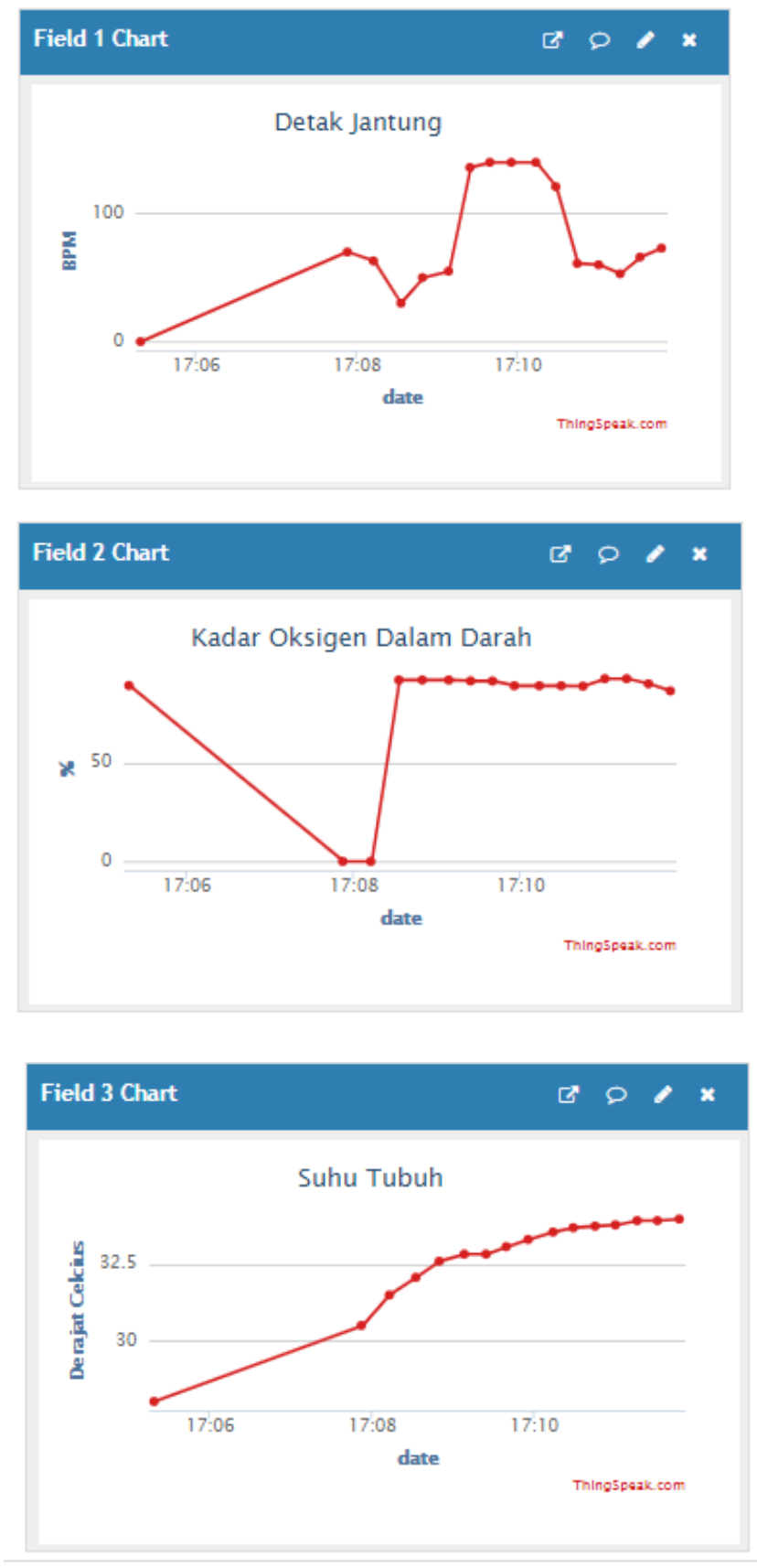

Gambar 4. Grafik Hasil Pengukuran pada tampilan ThingSpeak 
Hasil pengukuran ditampilkan dalam bentuk grafik yang mana dapat ditunjukkan dalam grafik pada Gambar 4.

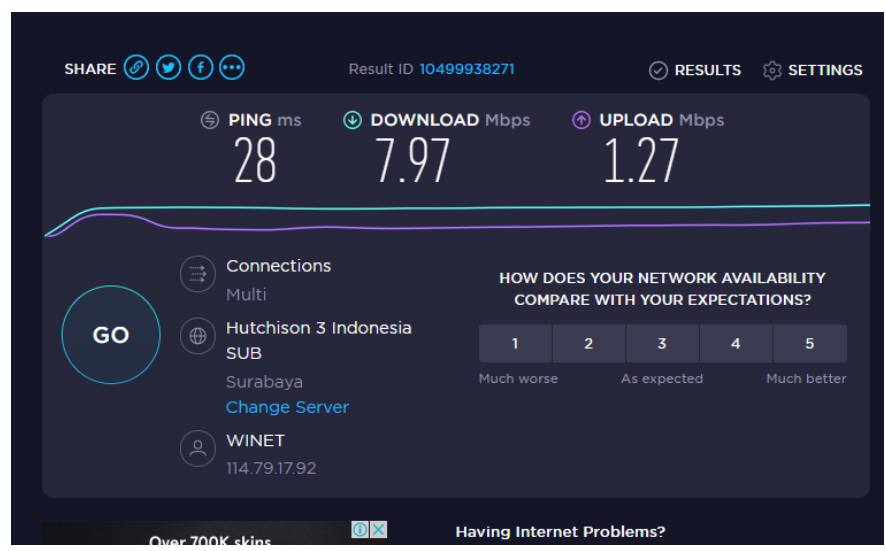

Gambar 5. speedtest.net

Pengukuran kecepatan jaringan internet menggunakan speetest.net (Gambar 5) dari hasil pengukuran tersebut didapatkan kecepatan jaringan internet sebesar 1,27 Mbps. Dalam kecepatan 1,27 Mbps tersebut ESP8266 mampu mengirimkan 16 data dari 220 data hasil pembacaan sensor dengan jeda sekitar 16 - 60 detik. Data yang ditampilkan dalam Thingspeak juga sudah sesuai nilainya dengan hasil pengukuran.

\section{KESIMPULAN}

Telah berhasil dibuat alat monitoring denyut jantung, saturasi oksigen dalam darah, dan suhu tubuh berbasis loT. Hasil ukur denyut jantung masih menunjukan error yang besar yakni sebesar $6,67 \%$ sedangkan hasil ukur saturasi oksigen dan suhu tubuh memiliki error relatif kecil yakni sebesar $1,19 \%$ dan $0,3 \%$. Hasil pengukuran dapat dilihat pada website Thingspeak.com dalam bentuk grafik. Pengiriman data dengan kecepatan internet 1,27 Mbps alat berhasil mengirimkan 16 dari 220 data dengan jeda 16-60 detik. Peletakan sensor denyut jantung yang tidak tepat memberikan error yang cukup besar.

\section{DAFTAR PUSTAKA}

Budi, D. B. S., Maulana, R., \& Fitriyah, H. Sistem deteksi gejala Hipoksia berdasarkan saturasi oksigen dan detak jantung menggunakan metode fuzzy berbasis arduino. Jurnal Pengembangan Teknologi Informasi dan IImu Komputer eISSN, 2548, 964X.

Chavan, S., Gadekar, P., Patil, M., Tondare, S., \& Gaikwad, S. Solar Powered NonInvasive Pulse Oximeter and Heart Rate Meter.

Gao, J., Tian, Z., \& Yang, X. (2020). Breakthrough: Chloroquine phosphate has shown apparent efficacy in treatment of COVID-19 associated pneumonia in clinical studies. Bioscience trends.

Kasdan, J., Baharuddin, R., \& Shamsuri, A. S. (2020). Covid-19 dalam Korpus Peristilahan Bahasa Melayu: Analisis Sosioterminologi (Covid-19 in the Corpus 
Of Malay Terminology: A Socio-terminological Analysis). GEMA Online $\AA$ Journal of Language Studies, 20(3).

KPCPEN. (2020). Gugus Tugas Percepatan Penanganan COVID-19. Satuan Tugas Penanganan COVID-19. Retrieved 18 Mei 2020 from https://covid19.go.id/

Lai, C.-C., Shih, T.-P., Ko, W.-C., Tang, H.-J., \& Hsueh, P.-R. (2020). Severe acute respiratory syndrome coronavirus 2 (SARS-CoV-2) and coronavirus disease2019 (COVID-19): The epidemic and the challenges. International journal of antimicrobial agents, 55(3), 105924.

Yurianto, A., \& Bambang Wibowo, K. (2020). Pedoman Pencegahan Dan Pengendalian Coronavirus Disease (COVID-19)(MI Listiana Azizah, Adistikah Aqmarina. Jarak antara kampus D Universitas Gunadarma Jl. Margonda Raya, 100. 